\title{
Barriers to Choice of Women Occupation in Warri Metrolpolis in Delta State, Nigeria
}

\author{
Edith Osiruemu
}

\author{
Department of History, Delta State University, Abraka, Nigeria
}

KEYWORDS Barriers; women; occupational choice; determinants; sex

ABSTRACT Barriers to women occupational choice in Warri metropolis are the focus of the paper. Empirical studies in the subject have thrown up conflicting conclusions as to the extent to which four factors namely the socialization process, sex stereotyping, self-concept and lack of motivation constitute barriers to occupational choice of women since the 1970's. Using a sample survey data of 240 professional women from ten establishments in Warri, this analysis from a three month field work show no significant relationship between these determinants as barriers to women's occupational choice. Rather, a significant shift into occupations not traditional to women is observed.

\section{INTRODUCTION}

If a society does not wage a common struggle to attain a common goal with its women and men, scientifically there is no way for it to get civilized or developed.

- (Atuturk, 1997)

If women and men have equal chances in life, Things will be different. We are working it out..., Women, men different but equal.

(Eoc, http.//eoc.org.uk.2006)

The thoughts expressed above concern the need to reduce segregation in a society, whether social, political or economic. This work is an expos on barriers to occupational choices of women in Warri Metropolis, Delta State, Nigeria.

Occupation as an indispensable factor in the life of an individual is incontrovertible. This is in the sense that the type of occupation, which an individual goes into, determines the way of life and how life is spent. In fact the world over today, "fashioning a work identity" translates into "fashioning an identity" (Gibbs and McRoy, 2006). In all cultures, personalities are identified by what they do. For the young, this question, in critical in determining the outcome of their lives.

It may be true that advancement in modern technology has created many new occupations that young people aspire into but recent surveys like that undertaken by the Gender Equity Advisory Committee (GAEC), Illinois in 2005 reveal that women continue to be over-represented in the lowest paid, lowest opportunity jobs in that economy. They comprise $79 \%$ of administrative support workers and only $2 \%$ of workers in construction trades. In 2005 as in 1998, the six leading occupations for women were still secretaries, nurses, beauticians, waitresses, teachers and cashiers. (GAEC, 2005). Reasons adduced for this situation is that female students were encouraged to explore career options based on their gender not abilities and interests. Thus gender-based obstacles appear in the early stages of formal instruction and continue throughout women's educational and career experience (GAEC, 2005).

In Britain as in Nigeria, while the percentage of women rose from $12 \%$ to $70 \%$ of the work force due to women's participation in further and higher education between the years, 1971 to 2004; distinct differences exist in the types of occupation entered by women and men. Women got more jobs in administrative, clerical, personal services and sales occupation, (Women and Work Commission, UK, 2005), (Ajayi, 2000), Apart from moving into law, medicine and accountancy, there was no similar movement into science, engineering, ICT and the skilled trades (http// www.eoc.org.uk; 2006). Women were not found in managerial occupations: overall, women make up only $32 \%$ of managers and senior officials (Women and Work Commission, 2005) while statistics collected by the Equal Opportunities Commission, show that $3 / 4$ of working women in Britain are still found in just five occupational groups and in the five 'c's - cleaning, catering, caring, cashiering and clerical. (http://www.eoc. org.uk, 2005).

In Pakistan, Bangladesh and Black Carribean Countries, while girls who are ambitious and forging ahead at school, but are more likely to face barriers in realizing their potential in the 
workplace because girls are not adequately prepared to make educated choices nor bias-free information which would have helped them eliminate gender-biased attitudes and behaviors made available to them (http://www.women and equality unit.gov.uk/research, 2005).

A project that investigated the impact of gender segregation of European labor markets on vocational training and education in the United Kingdom, Germany, Portugal and Greece in 2005 found that inspite of different industrialization and societal developments, women and men retained predominantly, expectations with regards to their self actualization and future occupational life. (http//www.pjb.co.uk 2006). Infact most exceptional young people had developed non-typical interests during their childhood, which was further developed during the school days, and the few occupational changes observable depended strongly on extraneous motivations. Conclusions: gender and gender role orientation were found to be predictive of sex-typed career aspirations thus gender segregation as far as male and female occupation has not reduced in the last decade (www./biat.uniflen.org; 2006); (Muldoon and Reilly, 2003), In concluding her survey on women and occupations in Nigeria, (Okoro, 1991) notes that apart from traditional humanist professions like nursing, teaching, catering and law, the percentage of women who venture into professions like engineering, architecture are low compared to men. (Okolo, 1995).

It is in this light that this paper avers two positions, the first is that women occupational aspiration is consequential upon their continued marginalization through stereophical information ingrained into young females, leading to wrong choices of career and job segregation in the Nigerian economy. Certain career counseling in the early stages of formal education as well as socialization processes have turned out to become gender-based obstacles to occupational choices. Secondly, observed ability of women to break into male dominated occupations in recent years is sequel of factors extraneous to existing situations.

Career development issue is a significant theme in recent gender discourse, which has engaged the attention of social historians, development psychologists and theoreticians. Indeed the career development movement, which began in the United States in the second half of the $20^{\text {th }}$ Century has spread to other nations and analysts assessing parallel factors critical to the growth of economies. The result is that within the past few years, socialization processes and career selection strategies selected by school counselors have been called into question. A sequential development is the evolution of two broad theoretical positions: the developmental and social cognitive, some of which are long tenured while others are newly evolving to address the emerging issues that gender and social class present. Researchers associated with the developmental view are Ginzberg et al. (1951), Super (1954) and Tie deman and O Hara (1963). Social cognitive career theorists include Roe (1956), Holland (1959, 1973) and Lent and Hackett (1994), Development research posits that occupation selection is a development process in which series of decisions are made over a period of time that is from preteen years, continuing through high school where interests in, capacity for and values of an occupational choice is defined (Ginzberg et al., 1951). That is, each step depends on the previous and succeeding stage. On the other hand, the social cognitive career theories (SCCT) focus upon the role of selfsystem, individual beliefs, inherent influence of the social and economic contexts of the development of the individual. (Lent and Hackett, 1994; Valiante, 1996).

Indeed in his pioneering study of factors influencing occupational choices in Nigeria; Aguisobo (1966), drawing heavily on Bandura (1965) had the following categories of factors:

- Socio-economic aspects of the environment - Personal or family factors

- Cultural factors.

Within these three factors are subsumed twelve dynamic determinants of occupational choice. These are intellectual ability; influence of school, family values, realism, family expectations, stereotypes, sex differences, socialization process, self-efficacy and self-competence, myth and conformity. While these factors may be true to the Nigerian Society at the period of Aguisobo's research, recent developments and researches have highlighted the dynamism of some of these factors as well as other factors extraneous to these determinants as determining occupational choices. Gibbs and McRoy (2006) for example, using Heidegger's theory on acquisition of craftsman and technical skills established that formalized and institutionalized education is much 
more paramount to the evolution and choice of career than traditional socialization process. (28393). In recent years too typical encouragement of gender role behavior is diminishing. (http// answers. gender roles, 2006).

For this reason empirical studies on these factors have resulted in divergent conclusions with regards to their influence on female choices of occupation in Nigeria. Ekejiuba, (1990) in her study on social mobility and changing status of Igbo women states that in terms of national development needs, women have remained invisible due to marginalisation and low self-esteem and efficacy. (10). Igbafe corroborates this view when he averred that it is not biological in capabilities that have hindered women from reaching their fullest potential in development rather cultural barriers expectations and conformity Osiruemu (2004); On the female gender and their occupational aspirations, Okonkwo (1980), Adugbo (1980) found sex to be a dominant factor in the sense that male students preferred realistic, investigative and enterprising occupations than females who are more interested in humanist, artistic, aesthetic, literacy, and clerical activities (see also, Engineering Council, Report, 1991). This view tallies with the conclusion of a 1994 report of the United States National Science Foundation (NFS) that an increase in the participation of women in occupation not traditional to them have occurred in the United States since the Educational Equity Act and Equal Employment legislations of 1972 in the sense that women who represented less than $1 \%$ of engineers in 1970 , had by $1990,17 \%$ of employed engineers (NFS, 1995). But that however, teachers have a major role to play in challenging children beliefs about what they can and cannot do. The problem of gender stereotyping is not differences but people writing themselves off from things unnecessarily. Therefore, teachers needed to be more aware of the extent and pervasiveness of gender stereotyping among young children and females who should be helped and encouraged to fully involve themselves in science and technology curricula (Engineering Council, 1995).

Like in the empirical studies above attempts by developmental psychologists to explain occupational choices of females in Nigeria have thrown up an intricate network of factors. Some of which are embedded in long tenured theories. Popular theories that can be gleaned from empirical studies are the socio-cultural theory, the self-concept theory and the social cognitive career theory (SCCT), the latter has incorporated in it, aspects of other theories and it is our focus below. In their detailed considerations of how culture, family background, social and economic conditions outside the control of an individual strongly influence one's identity, values and overall human and career development, Lent and Hackett (1994) who built on social cognitive theory of Bandura (1965) posits that through an evolutionary process beginning in early childhood and continuing throughout adulthood, one narrows the scope to successful endeavors, to focus on and form a career goal or choice.

The SCCT focuses on the connection of selfefficacy, outcome expectations and personal goals that influence and individual career choice. The beliefs the individual develops and refines through four major sources viz, personal performance accomplishment, vicarious learning, social persuasion and physiological state and reactions influence career choice. These aspects work together in the career development process in a way that individual develops ability for a particular endeavor and meets with success, which reinforces self- efficacy or belief in future continued success in the use of this ability. As a result one is likely to develop goals that involve continuing involvement in that activity. The contextual factors come into play by influencing the individual's perception of the probability of success. If the person perceives few barriers, the likelihood of success reinforces the career choice but if the barriers are viewed as significant, there is the weaker interests and choice actions (Stitt Gohdes, 1997). By adolescence, most people have a fair sense of the incompetence, along with convictions about the likely outcome of a career. Through a process of intervening learning experiences, that shape further one's ability and impacts, self efficacy and outcome beliefs one's vocational interests, choices and performances are shaped and reshaped (Savickes and Lent, 1994).

Through its focus upon the role of the selfsystem and the individual's beliefs, the SCCT extrapolates the process of career choice on gender typing. Efficacy beliefs contribute more heavily to occupational preferences. People with higher perceived self-efficacy to fulfill job functions consider a wider range of career options. Some people eliminate entire classes of vocations based on perceived efficacy. And 
women belong to this latter group in that they judge themselves less efficacious for scientific occupations than men. Since efficacy beliefs raise interest, they express lower sense of efficacy for occupation requiring quantitative skills and activities (Valiante, 1996), men and women often differ in their perceived capability to arrive at decisions about which career to pursue. Men may consider a wider range of options but family shapes women's beliefs about their capabilities and career options, parent expectations by sex, educational system, mass media and culture at large. (Valiante, 1996). Boys tend to inflate their sense of competence while girls generally disparage their capabilities. Parents and teachers expectations by sex are shaped by their belief that girls are less talented in mathematics than boys despite equal grades (Engineering Council, Repor, 1991). Although boys and girls do not differ initially in their perceived mathematic abilities, girls begin to lose confidence and diverge increasingly as time goes on. They avoid mathematic activities and class as creating the very gender differences parents originally presumed to exist. In the classrooms, the SCCT avers that teachers convey lower expectations of girls academically. School counselors encourage boys in scientific fields. For rates of academic failure, boys' failures are attributed to lack of effort while failures for girls are attributed to ability. This gender bias and stereotype career occupations exists even in as early as preschool where boys are ascribed with possessing higher intellectual capabilities than girls. Thus from the preschool age to adolescence where a sense of self-efficacy and competence is entrenched, women are cast in non-achieving roles, subordinate and emotional while men are cast as directive, venturesome enterprising, recreational. Through this socialization process, children grow into maturity to develop different interest. When time comes for them to make choices of occupation, the already internalized sex roles influence their choices. The SCCT concludes that although women make up approximately $50 \%$ of the total work force, they are not apt to choose technical and scientific careers. They typically maintain clerical, service or sales jobs and remain largely employed in traditionally female fields (Valiante, 1996).

Women, in particular are greatly affected by the early socialization already imbibed and strictly adhered to it (Afe, 1980). Gender stereotyping and socialization process thus constitute barriers. The concept of the socialization process as a barrier to women occupational choice is next examined.

\section{The Concept of Barrier as a Determinant of Choice of Women Occupation}

Barrier may be defined as any obstacle, boundary or agency that keeps apart. It is an obstruction that prevents access or halts advance. Following from the above, barrier can mean a restriction, a hindrance or stratification of some sort to a level at which an individual aspires. In some fields of analysis within the social sciences and humanities, the issues associated with the explanation of the concept of barriers in choice of women occupation are intricately interwoven with definitions of gender role and socialization processes in societies. Whether western or non western, gender role is the pattern of masculine or feminine behavior of an individual that is defined by a particular culture and it is largely determined by a child upbringing. Gender role has one meaning; the overt expression of attitudes that indicate to others the degree of your maleness or femaleness. A gender role is a set of behavioral norms associated with males and females respectively in a given social group or system (Reiter, 1957). Most researchers recognize that the concrete behavior of individuals is a consequence of both socially enforced rules and values and individual disposition whether genetic, unconscious or conscious. Creativity may cause rules and values to change overtime although such changes are also subject to intense debates where they concern the gender/sex system and how much gender depend on biological sex, and the total dissolution of barriers between the sexes (Talcott, 1955).

The process through which the individual learns and accepts roles is called socialization. Socialization works by encouraging wanted and discouraging unwanted behavior. In societies, the agencies of socialization such as family, schools, peer group and the media make it clear to the child what behavioral norms the child is expected to follow, and once someone has accepted a set of behavioral norms, they are typically very important to the individual. Hence, the internalization of these behaviors and beliefs, based on society's awareness and expectations lead to special interest which impact on vocational choices (Gender Roles; Answers.com, 2006). In all societies whether western or non western, 
women appear to have been brought up to believe in and adhere to gender roles which are conveyed to them on a daily basis. These beliefs are so ingrained into the females that they are extended to vocational choices (Valiante 1996). As Lofland (1969), avers, the greater the consistency, duration and intensity with which a definition is promoted by others about an actor, the great the likelihood, the actor will embrace that definition as truly applicable to himself (324). This seems to be the case with the young females in societies. The EOC Report (2005) argues along this line when it points out that it is not only overt socialization or covert prejudicial attitudes held by the society that keeps the females from entry into skilled jobs but the women themselves lack the courage to enter the field because they see the requirements for successful performance in such areas, as incongruent with the way they see themselves (Women and Work Commission, 2006).

The genders role and self-efficacy barrier constitute real problem for Nigeria adolescent females (Afe, 1980). Self-efficacy as conceived by Olowo (1985) is the conceptualization by the individual of his own person. This opinion of self is formed through subjective beliefs and factual knowledge the individual ascribes to himself. Valiante (1996) emphasizes that an individual's self concept is closely related to his choice of occupation. By expressing a vocational preference, an individual reveals the kind of person he or she is (3). Relating this conception of selfconcept to future roles, he posits that a woman's aspiration does not go beyond the scope defined by the self-awareness; a major determinant and barrier factor in female choice of occupation. Relating this view to the Nigerian situation, Ipaye (1986) explains that the Nigerian Society trains the males for super-ordinate roles whereas the females are trained for subordinate roles in line with dictates of the socialization process. Boys are prepared for occupations, which ensures their status in the society while the girls are prepared for their role as nurturers and loving homemakers.

It may be obvious from analysis so far that the society's gender/sex role system and socialization process constitute barriers to women's choice of occupation. Majority of the women who would have excelled in occupation considered to be non traditional have been counseled into humanist professions without cognizance of individual capabilities and dispositional attitude (Maisamari, 2002).
It is in light of the above that this study investigates the implication of the societal socializations processes in terms of sex role stereotyping, selfconcept and motivation on women's occupational choice in Warri metropolis. As an already highlighted, recent studies on determinants of women's occupational choices in Nigeria have thrown up conflicting findings. While Ipaye (1986) and Ajayi, (2000), concluded that these determinants outlined above constitute barriers, Atiba, (1988) argue on the contrary, that is, no significant relationship exist between these determinants and women's choice of occupation.

Warri is the largest urban center in Delta State, Nigeria; with a population figure of 217,504 by the final projection of the 1991 census (Ministry of Finance and Economic Development; 1992). Founded during the second half of the nineteenth century, geographically, Warri is located at the point of transition from the palm groove belt into the rain forest. The Urhobo, Itsekiri and Izon ethnic groups, which are distributed for administrative purposes, into three local government areas; Warri South West, Warri North and Warri South, people it predominantly.

\section{METHODOLOGY}

The barriers to the occupational choice of women were investigated between March and June 2004. Using the descriptive survey design, the target population was professional women in the metropolis. To collect data and ensure that all categories of professional women were represented, a sample of 240 women with the following qualifications was used: West African School Certificate (WASC) holders, Grade two teachers, National certificate of Education (NCE), nurses, clerks, Ordinary National and Higher National Diploma (OND/HND) holders, Bachelors degree and higher degree holders. This sample, which was randomly selected, was further narrowed down to 120 women from ten available establishments in the three local governmental areas in the metropolis.

The questionnaire adapted after Morakinyo (1985) four-point rating scale of strongly agree, agree, disagree and strongly disagree was used. It was however, collapsed into agree/disagree categories in order to reduce the scale to a nominal one. The adapted instrument measuring the barriers, validity and reliability test was done on 30 professional women while the test - retest of 
instrument was conducted on same respondents within a four-week interval. The relatively index which was calculated using Pearson product moment correlation was found to be 0.85 approx.

\section{FINDINGS}

On reasons for present choice of occupation, $16.7 \%$ of the respondents claimed that they got their choice professions while $25 \%$ nearly got the occupation they preferred and $58.3 \%$ of them did not get the occupation of their choice. These latter believe that their career choices would have been different had they been aware of implications of their choices (Table 1A and 1B).

From Table 2, the null hypothesis of no significant relationship between societal sex roles stereotypes and women's choice of occupation is accepted. This is based on the calculated value of $\chi^{2}$ which, is 14.067 depicting no significant relationship. This finding, no doubt is at variance to Ipaye, (1986) and Ajayi (2000) that women's aspirations do not go beyond the scope so defined for them by the society. Rather the onset of industrial and technological advancements, and in the age of educational egalitarianism women appear to have ventured into occupations such as engineering, geology, armed forces, medicine and other professions considered non traditional to them. More women even acquired masters and doctoral degrees beyond the home and first degree. As Atiba, 1988 points out, the number of women found in male dominated occupations like medicine, law, banking have been on a steady rise since 1970.

On the relationship between societal sex role stereotypes and women's choice of occupation. Summary of the responses show 83 or $35.58 \%$ agreeing while 157 making up $65.42 \%$ of the respondents disagreeing on the influence of the societal sex role differentiation as leading to their choice of occupation. This leads to the conclusion that no relationship exists between societal sex role stereotypes and women's choice of

Table 1A: A sample table of the subjects following their present occupations, reasons for present occupations, and the occupations preferred.

\begin{tabular}{llll}
\hline S. No. & Present Occupations & Reason for Present Occupation & Occupation Preferred \\
\hline 1 & Medical Practitioner & Influenced by parents & Same \\
2 & Legal Practitioner & Interest & Law \\
3 & Librarian & Personal interest & Librarian \\
4 & Confidential Secretary & Interest & Confidential secretary \\
5 & Teaching & No guidance & Education Officer \\
6 & Nursing & To care for humanity & Medical Doctor \\
7 & Nursing & University offer & Education officer \\
8 & Teaching & To interact with people & Medical Doctor \\
9 & Nursing & Lack of sponsor & Medicine \\
10 & Nursing & To care for others & Human Resource Person \\
11 & Teaching & The job I got & Medicine \\
12 & Teaching & My husband preferred it & Medicine \\
13 & Teaching & Husband's choice & Engineering \\
14 & Teaching & Lack of money to do business & Business \\
15 & Caterer & Available job & Banking \\
16 & Clerical Assistant & Financial constraint & Business \\
17 & Teaching & My friend influenced me & Nursing \\
18 & Civil servant & Available one & Law \\
19 & Teaching & My parents wanted it & Nursing \\
20 & Teaching & What university offered me & Accountancy \\
21 & Banking & Attractive salary & Teaching \\
22 & Teaching & Financial constraint & Engineering \\
23 & Teaching & Lack of guidance & Business Administration \\
24 & Teaching & By chance & An Administrator \\
\hline
\end{tabular}

Table 1B: Responses and Percentages.

\begin{tabular}{lrr}
\hline & Responses & Percentages \\
\hline Women who got the occupation they preferred & 40 & $16.7 \%$ \\
Women who nearly got the occupation they wanted & 60 & $25.0 \%$ \\
Women who did not get the occupation they preferred. & 140 & $58.3 \%$ \\
Total Number of Respondents & 240 & $100.0 \%$ \\
\hline
\end{tabular}

Source: Field data 
Table 2: Summary Table of $\chi^{2}$ analysis of the relationship between a societal sex role stereotypes and women's choice of occupation.

\begin{tabular}{|c|c|c|c|c|c|c|c|c|}
\hline \multirow[t]{2}{*}{ Group } & \multicolumn{3}{|c|}{ Societal sex role stereotypes } & \multirow{2}{*}{\multicolumn{2}{|c|}{$\begin{array}{c}\chi^{2} \\
\text { calculated }\end{array}$}} & \multirow{2}{*}{$\begin{array}{c}\chi^{2} \\
\text { critical }\end{array}$} & \multirow{2}{*}{$\begin{array}{c}\text { Level of } \\
\text { insignificance }\end{array}$} & \multirow[t]{2}{*}{ Remark } \\
\hline & Agree & Disagree & Total & & & & & \\
\hline Teachers & 39 & 81 & 120 & \multirow{8}{*}{7} & & & & \\
\hline Civil servants & 18 & 33 & 51 & & & & & \\
\hline Nurses & 17 & 26 & 43 & & & 14.067 & & \\
\hline Bankers & 2 & 4 & 6 & & & & & \\
\hline Secretaries & 2 & 5 & 7 & & & & & \\
\hline Doctors & 1 & 5 & 6 & & 4.21 & & 0.05 & Insignifican \\
\hline Lawyers & 1 & 2 & 3 & & & & & \\
\hline Business -women & 3 & 1 & 4 & & & & & \\
\hline Total & 83 & 157 & 240 & & & & & \\
\hline
\end{tabular}

occupation. In fact a significance test $\left(\chi^{2}\right)$ showed a 0.05 level (Table 2).

On the relationship between self-concept and women's choice of occupation, the response show that $55 \%$ of the respondents agreeing while $45.4 \%$ of them disagreeing, showing no significant relationship between self-concept and career choices of women that is, women's career aspiration do not go beyond the scope perceived as suitable feminine jobs. The finding rather confirms the self -concept position by Ellis and Davis (1982) that self comprises a set of ideas about oneself although these perceptions may not match their feeling. When such persons are subjected to extraneous influence demonstrate behaviors and attitude completely at variance to perceived perception of self (685-705). The above seems to be the palpable explanation for young females being able to set aside self-concept and go ahead to pursue courses of interest and ability with very little guidance from their parents. (Ajuyah, 2001)

Similarly, the findings from responses show a variance to Ogunlade (1978) conclusion that women who are low in achievement motivation (self efficacy) are incapable of striving for high caliber career outside the home. This is in the sense that the variables of shyness, and selfconsciousness, which are correlates of low self esteem persons, also affect women. With 150 respondents making up 63\% agreeing and 38\% of the respondents disagreeing. The chi-square $\left(\chi^{2}\right)$ test of performance was at 0.05 level of significance. What this means is that no significant relationship exist between lack of achievement motivations and women's choice of occupation. These findings point to the fact that individual differences exist among the females. Some manifest motivations to more traditionally masculine careers than vocations for women.

\section{CONCLUSION}

From the analysis so far, it is obvious that occupational choices of women in Warri metropolis have not been hampered by societal sex roles stereotypes, self-concept and lack of achievement motivation barriers. This may be attributable to the introduction of guidance and counseling programmes in schools. More than that the emerging trend that men and women can share similar occupation suggest that the sex one is born into does not determine one's ability and capabilities. This issue of tasks conventionally assigned to sex is gradually fading away.

Many parents now realize the importance of equal educational opportunities at all levels to both male and female children and this has helped to modify the early socialization of boys and girls and has created a bias free atmosphere. Consequently, the negative self-concept of girls being inferior, weaker vessels and minor to boys has gradually been eroded by developments in the society. Moreover, media highlights on females holding highbrow corporate and administrative jobs have ingrained the desire in women to aspire into such fields. It can therefore be conclusively said that these factors considered in this study no longer constitute much hindrance to women's choice of occupation.

\section{REFERENCES}

Adugbo, A. J. 1980. The Effect of Academic Performance and Counseling on Choices of Selected students in Bendel State. Ph.D Thesis, Unpublished, University of Lagos. Lagos State.

Aguisiobo, O.N. 1966. Personal Factors Influencing Undergraduate at the University of Nigeria. Ph.D Thesis, Unpublished, University of Wisconsin.

Afe, J 1980. "Some Factors Which Influence Achievement Motivation in Women." Education, 15(3): 15-21 
Ajayi, B.T. 2000. Relationships among Locus of Control, Self-esteem and Achievement Motivation of Women in Colleges of Education, Kwara State. Ph.D Thesis, Unpublished, University of Ilorin, Ilorin.

Ajuyah, J.E. 2001. An Investigation of Parental Influence on Educational and Vocational Choices of Secondary School Students in Warri South Local Government Area of Delta State. Ph.D Project, Unpublished, Delta State University, Abraka.

Atiba, T. 1988. Self-concept and Vocational Interest of Students in Selected Secondary Schools in IjebuOde Local Government Area of Ogun state". M.A. Dissertation Unpublished, University of Benin, Benin City.

Atuturk, K. M 1997, cited in Burcak, K. 2006. "Political participation by Turkish women, Middle East Review of International Affairs." (Meria Journal) Dec. Retrieved, sept.30, 2000 from http//www/hb.cornell. edu/colldev/mid east, 2006

Bandura, A. 1965. "Influence of Model's Reinforcement Contingencies on the Acquisition of Imitative Responses." Journal of Personality and Social Psychology, 1: 589-595.

Benokraitis, N.V. (Ed.). 1997. Subtle Sexism: Current Practice and Prospects for Change. Thousand Oaks, CA: Sage.

Crites, J.O 1969. Vocational Psychology: New Jersey; McGraw-Hill Book Co. "Effects of career choice against gender structures", 2005, Part 2. Retrieved October 7, 2006 from http//www.pjb.co.uk. Part 2

Ekejiuba, F. 1990. "Social Mobility and Changing Social Status of Igbo Women." A paper presented at a seminar on women: A vital link in Development. Statesman, Daily Newspaper Owerri April 8.

Ellis, D and Davis L.T 1982. "The Development of Self-concept Boundaries Across the Adolescent Years." Adolescence, 17(67): 685 - 708.

Equal Opportunities Commission, 2005. Retrieved October 7, 2006 from http://eoc.org.uk. 2006

Engineering Council Research, 1991. cited in "Barriers in Early School years", Chap. 2 2000, retrieved. October 8, 2006 from http://www.Iboro.ac.org/ opp2000/chap 2a.htm.

Farmer, H.S. 1997. Diversity and Women's Career Development; From Adolescence to Adulthood. Thousand Oaks, CA; Sage.

Foster, G.M. 1962. Traditional Cultures and the Impact of Technological Change. New York.: Harper and Row.

Gender Equity Advisor Committee (GAEC) of the Illinois state Workforce Board, 2006.

Gender and Qualifications, Part 2, 2006. Retrieved October 7, 2006 http://www/pjb.co.uk/npl

Gibbs, P and I. McRoy. 2006. "Dwelling at work: a place where vocation and identity would grow." Journal of Further and Higher Education, $30(3): 283-93$

Retrieved on October 10, from http://www.ingenta connect.com/content/outedg/cjfh

Ginzberg, E., S. W. Ginzberg, S. Axelrad and J. I. Heman. 1951. University Occupational Choice; An Approach to a General Theory. New York: Columba Press.

Hermain, D.D. 1974. "More Career Opportunities of Women: Whose Responsibility." Personal Journal, 11: 417.
Holand, J.L. 1973. Making Vocational Choices: A Theory of Careers Engel wood Cliffs. N.J.: Prentice Hall, Inc.

Igbafe, P.A. Cited in Uku, P. 1991. Women in Politics (pp 26 - 29) in Chizea D.O,Njoku J. (ed), Nigerian Women and the Challenges of our Times. Lagos Malthouse Press Ltd.

Ipaye, T. 1986. Education and Vocational Guidance: Concepts and Approach. Ife: University of Ife Press Ltd.

Jacobs, J.A 1992. "Women's Entry into Management: Trends in Earnings, Authority, and Values Among Salaries Managers. Special issue: Process and outcome: Perspectives on the Distribution of Rewards in organizations." Administrative Science Quarterly, 37: 282-301.

Klein, S. 1995. Handbook of achieving sex Equity through Education Baltimore M.D.: John Hopkins University Press.

Kohlberg, L. 1966. “A Cognitive-Developmental Analysis of children's sex role concepts and Attitudes", (Pp. 82-173) in E.E Maccoby (ed.) The Development of Sex Differences. Stanford C.A. Stanford University Press

Lent, B. and G. Hackett. 1987. "Social Cognitive Career Theory." Retrieved. September 27, 2006 from http://www.extension.psu.edu.workforce.

Linton, R. 1973. The Study of Man. New York: AppletonCentury Crofts.

Lofland, J. 1969. Deviance and Identity. Englewood Cliffs, NJ: Prentice Hall.

Lorber, J. 1993. Paradoxes of Gender. New Haven.: Yale University Press.

Morakinyo, A. 1987. "Vocational Counseling." The Nigerian Journal of Guidance and Counseling, 3: 182.

Maisamari, J.Y. 2002. "Choosing the Right Career: What Approach? Implications for Career Counseling of Secondary School Students." The Nigerian Journal of Guidance and Counseling, 8(1): 41-44.

Megargee, E.I. 1979. "Influence of sex role on manifestation of Leadership." Journal of Applied Psychology, 53: 377-882.

Muldoon, O. T and J. Reilly. 2003. "Career Choice in Nursing Students: Gender constructs as psychological barriers." Journal of Advanced Nursing, 43(1): 93100

National, Science Foundation. 1994. Request for Proposals. Washington DC: US Government Printing Office.

National, Population Commission, Census. Report, 1991. Ministry of Finance and Economic Development. Lagos, Nigeria: Federal Government Press.

Ogunlade, J.O. 1978. "Sex differences in Achievement motivation among some Nigerian Adolescents." Nigerian Journal of Psychology, 2: 57-59.

Okolo, I. 1995. "Women in the Legal Profession in Nigeria: Problems and Prospects." Daily Times, July 9,5

Okonkwo, B.C. 1980.”Some Determinants of Vocational Preferences Among Nigerian Secondary School Students." Unpublished paper, University of Ibadan. Ibadan

Okoro, C. 1991, "Counseling for Women in National Development: A Conceptual Framework". (pp18- 
23) In Unachukwu G.C. and Igborgbor, G.C (ed). Guidance and Counseling": A Realistic Approach. International Universities Press. Owerri.

Olowu, A.O. 1985. "Gender as a Determinant of some Nigerian Adolescent Self-Concept." Journal of Adolescents, 8:347-355.

Osiruemu, E. O. 2004. "Women's Quest for Political Authority in Nigeria: The Barriers." Global Journal of Humanities, 3(1 and2): 72-75.

Reiter, P. 1975. cited in Gender Roles. Answers.com. Retrieved October 8, 2006 from http:// www.answers.com, Oct. 8, 2006

Roe, A. 1962. The Psychology of Occupation. New York: John Weily and Sons Inc.

Savickes, M. and R. Lent. 1994. Convergence in Career Development Theories. California: Palo Alto Consulting Psychologist Press Inc.

Sosanya, M.S. 1980. A Survey of Vocational Interest of Some Selected Nigerian Adolescents. B. Ed Project. Unpublished, University of Ibadan. Ibadan.

Stitt - Gohdes, W. 1997. Career Development. Ohio: Eric Clearing House on Adult.

Super, D.E. 1951. "Vocational Adjustment: Implementing a self -Concept." Occupation, 30(2): 88-92.
Super, D.E. 1963. Career Development and Self-concept Theory.

Princeton, New Jersey: College Entrance Examination Board..

Talcott Parsons cited in Gender Role. 2 Answers.com. Retrieved October 8, 2006 from http://www.answers. com.uk. Gender roles / topic.

Tiedemann, S. and O. Hara. 1963. cited in Gender Roles 2. Retrieved October 8, 2006 from http:// www.answers.com.uk. Gender roles / topic.

Uka, N. 1973. "The Nigerian Youth and Vocational Education." West African Journal of Education, 17(1): 39-43.

United Nations. 1991. The World's Women 1970-1990: Trends and Statistics. New York: United Nations.

Valiante, G. 1996. "Self Efficacy: The Exercise of Control; Bandura." An Outline. Retrieved on October 12, 2006 from http://www.answers.com.uk.genderroles.

Wajeman, J. 1998. Managing like a man: Women and Men in Corporate Management. Cambridge: Polity press.

Women and work Commission, 2005. Retrieved October 8, 2006 from http://www.womenandequalityunit.gov. uk/research 